\title{
PENINGKATKAN KOMPETENSI LITERASI ANTIRADIKALISME MELALUI PENULISAN CERITA RAKYAT DENGAN APLIKASI BABOO
}

\author{
Yanuar Bagas Arwansyah ${ }^{1}$, Urip Muhayat Wiji Wahyudi ${ }^{2}$ \\ ${ }^{1}$ Pendidikan Bahasa dan Sastra Indonesia, ${ }^{2}$ Pendidikan Guru Sekolah Dasar \\ Universitas PGRI Yogyakarta \\ E-mail: yanuarbagasa@upy.ac.id,muhayat@upy.ac.id
}

\begin{abstract}
Abstrak:
Peningkatan kemampuan masyarakat dalam memahami informasi yang diterimanya menjadi salah satu sarana untuk mencegah masuk dan berkembangnya paham radikalisme di dalam masyarakat.Penelitian ini bertujuan untuk mengetahui peran menulis cerita rakyat dengan aplikasi Baboo dalam meningkatkan kompetensi literasi antiradikalisme siswa sekolah dasar. Hasil dari uji ahli pertama dan ahli kedua dalam penelitian ini menunjukkan bahwa penulisan cerita rakyat berlandaskan ideologi Pancasila dengan aplikasi Baboo mendapat nilai sangat baik. Ahli pertama yang mengamati tentang kelayakan penggunaan media memberi nilai 92 (sembian puluh dua), sementara ahli kedua yang mengamati tentang kelayakan materi cerita rakyat memberi nilai 90 (sembilan puluh). Bahan ajar kumpulan cerita rakyat juga terbukti mampu meningkatkan kompetensi literasi antiradikalisme ditunjukkan dari peningkatan nilai hasil dari pre-test dan posttest tentang antiradikalisme, yang mana nilai rata-rata pre-test yaitu 55 (lima puluh lima) dan nilai rata-rata post-test siswa 90 (sembilan puluh). Produk dari penelitian ini berupa buku kumpulan cerita rakyat berlandaskan ideologi Pancasila sebagai bahan ajar. Setelah dilakukannya uji oleh kedua ahli tersebut, selanjutnya dilakukan uji oleh praktisi yaitu dengan melaksanakan Focus Group Discussion (FGD), berdasarkan hasil FGD disimpulkan bahwa buku kumpulan cerita rakyat dan cerita rakyat online dalam aplikasi Baboo dinyatakan layak digunakan sebagai bahan ajar di sekolah dasar. Produk akan diimplementasikan oleh guru dan mahasiswa PGSD Universitas PGRI Yogyakarta sebagai bahan ajar di sekolah dasar.
\end{abstract}

Kata kunci: literasi, antiradikalisme, aplikasi Baboo, Pancasila

\section{PENDAHULUAN}

Kemajuan teknologi dan informasi yang sangat pesat menuntut peningkatan kompetensi di berbagai bidang. Peningkatan kompetensi literasi menjadi salah satu hal yang penting untuk ditingkatkan dalam menghadapi perkembangan teknologi dan informasi. Selain itu, munculnya tantangan revolusi industri 4.0 yang mana segala bidang telah memanfaatkan telekomunikasi dalam jaringan, maka peningkatan kompetensi literasi menjadi vital perannya untuk terus dapat memenuhi tuntutan yang ada.

Melihat data literasi Indonesia, studi UNESCO dengan judul The Most World's Literate Nations pada 2017 merilis peringkat Indonesia dalam minat membaca yang berada di peringkat 60 di atas Botswana (Hutapea, 2019). Hal ini tentu menjadi catatan kurang baik untuk budaya membaca di Indonesia.

Keterampilan berbahasa terbagi atas keterampilan reseptif dan produktif. Kompetensi literasi terdiri atas kemampuan membaca dan menulis, sehingga kompetensi ini menuntut keterampilan reseptif dan produktif (Kayati, 2019). Peningkatan kemampuan masyarakat dalam memahami informasi yang diterimanya menjadi salah satu sarana untuk mencegah masuk dan berkembangnya paham radikalisme di dalam masyarakat. Radikalisme adalah suatu paham yang dibuat-buat oleh sekelompok orang yang menginginkan perubahan atau pembaharuan sosial dan politik secara drastis dengan menggunakan cara-cara kekerasan (Yunus, 2017). Masyarakat dituntut mampu memilih dan memilah informasi yang diterimanya sehingga dapat terfilter informasi yang mengandung radikalisme.

Selain kemampuan dalam memilih dan memilah informasi yang diterima, masyarakat juga diharapkan mampu memproduksi informasi tertulis yang tidak mengandung unsur radikalisme. Salah satu hal yang tidak mengandung unsur radikalisme dan dapat memberikan nilai-nilai pendidikan adalah cerita rakyat. Cerita rakyat merupakan cerita yang berkembang dalam masyarakat dan disebarkan 
dari mulut ke mulut antargenerasi yang mengandung pesan moral dan nilai-nilai pendidikan karakter. Cerita rakyat dapat menjadi media yang tepat dalam menanamkan nilai-nilai ideologi Pancasila pada anak usia sekolah dasar untuk mencegah masuknya paham radikalisme.

Menulis cerita rakyat dalam revolusi industri 4.0 ini dapat dilakukan dengan menulis secara online di platform-platform yang sudah ada agar dapat diakses dan dikonsumsi oleh masyarakat luas. Sarana membaca dan menulis online telah banyak tersedia, salah satunya adalah aplikasi Baboo. Aplikasi Baboo adalah aplikasi membaca dan menulis secara online yang dapat diakses melalui laptop, gadget, ataupun smartphone. Media pembelajaran berbasis aplikasai android sebagai salah satu cara efektif, dikarenakan peserta didik memiliki peningkatan dan motivasi lebih dalam kegiatan belajar dan pembelajaran (Mubarok \& Pheni, 2019).

Kepala BNPT menilai bahwa teknologi dan informasi telah mengubah tatanan sosial, dibutuhkan peningkatan pendidikan karakter siswa guna membentengi diri dari pengaruh radikalisme yang tidak sesuai dengan falsafah Pancasila. Nilai-nilai Pancasila di sekolah yangkini semakin melemah dinilai menjadi faktor berkembang pesatnya paham radikalisme. Data tentang perkembangan informasi di kalangan siswa, hasil survei Lembaga Penelitian dan Survei Pelajar-Pemuda PW Ikatan Pelajar Nahdlatul Ulama (IPNU) Jawa Timur tahun 2016 menunjukkan $50 \%$ pelajar menggunakan smartphone sejak sekolah dasar (SD) dan $44 \%$ menggunakannya sejak SMP serta $3 \%$ sejak SMA. Berdasar pada data tersebut urgensi dari penelitian ini yaituperlu adanya pembatasan dalam penggunaan smartphone pada anak usia sekolah dasar, yaitu memberikan pemahaman antiradikalisme melalui bahan bacaan yang dapat diakses melalui smartphone dan memanfaatkan smartphone sebagai media belajar siswa, salah satunya penggunaan aplikasi Baboo sebagai media belajar digital.Penelitian ini bertujuan untuk mengetahui peran menulis cerita rakyat dengan aplikasi Baboo dalam meningkatkan kompetensi literasi antiradikalisme siswa sekolah dasar.

\section{METODE}

Penelitian ini merupakan penelitian pengembangan (Research and Development) dengan model pengembangan Borg \& Gall (1979). Secara operasional langkah-langkah penelitian dijabarkan dalam tiga tahap, yaitu tahap prasurvei, tahap pengembangan media, dan tahap pengujian media. Pada tahap awal dilakukan prasurvai yang berguna untuk (1) mengidentifikasi ruang lingkup masalah; (2) mengidentifikasi bentuk-bentuk radikalisme di sekolah. Proses pengidentifikasian dilakukan melalui studi literatur/pustaka dan Focus Group Discussion (FGD). Hasil prasurvei digunakan sebagai bahan pertimbangan untuk mengembangkan media Baboo sebagai bahan ajar meningkatkan kompetensi literasi melalui penulisan cerita rakyat antiradikalisme berlandaskan ideologi Pancasila.

Persiapan yang dilakukan dengan mempersiapkan perangkat penelitian setelah menganalisis program yang ada di lapangan. Kegiatan pada tahap ini meliputi analisis permasalahan, dan analisis konsep.

\section{Analisis Permasalahan}

Pada tahap analisis permasalahan ini, peneliti melakukan wawancara pada 5 (lima) orang siswa tentang apa yang dipahami mereka mengenai paham radikalisme. Selain itu, peneliti juga melakukan wawancara kepada guru dan kepala sekolah tentang sejauh mana pemberian pemahaman antiradikalisme pada siswa. Berdasarkan hasil wawancara, sebagian besar siswa yaitu 4 siswa belum memahami apa makna radikalisme yang sebenarnya, sedangkan satu siswa dapat memahami makna radikalisme meskipun belum sepenuhnya. Sementara itu, dari guru dan kepala sekolah menyampaikan bahwa belum banyak pembelajaran yang menyinggung tentang makna radikalisme, sehingga perlu adanya materi dan bahan ajar yang mendukung adanya penyampaian konsep antiradikalisme pada anak-anak. Wawancara dilanjutkan kepada guru dan kepala sekolah tentang buku ajar yang digunakan di sekolah dalam mengajarkan makna radikalisme. Hasil wawancara menunjukkan bahwa buku ajar yang digunakan sejauh ini untuk mengajarkan paham antiradikalisme adalah buku Pendidikan Kewarganegaraan, meskipun tidak secara spesifik menjelaskan tentang antiradikalisme.

Pada tahap ini peneliti juga menanyakan perihal penggunaan teknologi dalam pembelajaran di kelas. Hasil keterangan guru dan kepala sekolah menyatakan bahwa penggunaan teknologi dalam pembelajaran masih cenderung pada penggunaan komputer sekolah untuk pembelajaran TIK. Sementara untuk pembelajaran di kelas menggunakan video dan 
power point. Penggunaan aplikasi pada gadget ataupun laptop masih jarang dilakukan mengingat tidak semua siswa memiliki laptop. Analisis permasalahan ini dilakukan pada periode Mei 2019.

\section{Analisis Konsep}

Analisis konsep dilakukan dengan memberikan materi tentang antiradikalisme pada guru, kepala sekolah, dan siswa SD Negeri Tinom, Godean, Sleman. Selain itu, dilakukan pula pengenalan konsep cerita rakyat berlandaskan ideologi pancasila untuk memberikan pemahaman tentang manfaat cerita rakyat untuk meningkatkan pemahaman siswa paham antiradikalisme. Selanjutnya diperkenalkan aplikasi Baboo sebagai media belajar siswa berbasis android atau gadget. Hal ini ditujukan untuk memanfaatkan perkembangan teknologi dalam dunia pendidikan.

\section{HASIL DAN PEMBAHASAN}

Tahapan pelaksanaan penelitian diawali dengan studi pendahuluan (need assessment), penyusunan instrumen, penyusunan buku kumpulan cerita rakyat, uji buku ajar oleh ahli dan revisi buku ajar. Adapun rincian penjelasannya adalah sebagai berikut:

\section{Studi Pendahuluan (need assessment)}

Pelaksanaan studi pendahuluan dilakukan untuk mengetahui kebutuhan awal sebelum menyusun buku ajar. Penyusunan buku ajar ini melibatkan dari tim ahli, guru, dan kepala sekolah. Dalam melakukan need assessment untuk siswa, dilakukan dengan cara memberikan instrumen kepada siswa yang akan diisi oleh siswa.

Selain itu, studi pendahuluan dilakukan dengan wawancara terhadap guru, kepala sekolah, dan siswa SD Negeri Tinom, Godean, Sleman. Hasil wawancara ini nantinya akan sebagai dasar dalam pembuatan program. Hasil dari guru, kepala sekolah, siswa, dan stake holderakan dijadikan dasar dalam pembuatan buku kumpulan cerita rakyat berlandaskan ideologi Pancasila.

\section{Penyusunan Instrumen}

Instrumen yang disusun dalam penelitian ini yaitu instrumen untuk ahli dan praktisi. Penyusunan instrumen dilakukan dengan melihat isi dari buku kumpulan cerita rakyat yang akan diberikan penilaian. Sehingga instrumen penilaian dari ahli tidak keluar dari isi buku tersebut. Kemudian, instrumen tersebut diberikan ke ahli instrument untuk diberikan penilaian kelayakan instrumen. Hal ini dilakukan untuk menjaga penilaian yang akurat terhadap apa saja yang diberikan penilaian dan kesesuaian kalimat. Ahli yang dilibatkan dalam menilai untuk kelayakan instrumen yaitu Luqman Hidayat, M. Pd. Pelaksanan penyusunan instrumen dilakukan pada bulan Mei sampai dengan Juni 2019.

\section{Penyusunan Bahan Ajar}

Berdasarkan hasil dari need assessment tersebut, maka disusunlah kumpulan cerita rakyat berlandaskan ideologi Pancasila. Buku kumpulan cerita rakyat berlandaskan ideologi Pancasila ini disusun dengan beberapa komponen di bawah ini:

Bagian 1
a) Pengertian cerita rakyat
b) Unsur-unsur cerita rakyat

Bagian 2
a) Radikalisme
b) Nilai-nilai Kebangsaan

Bagian 3

Cerita rakyat di Indonesia

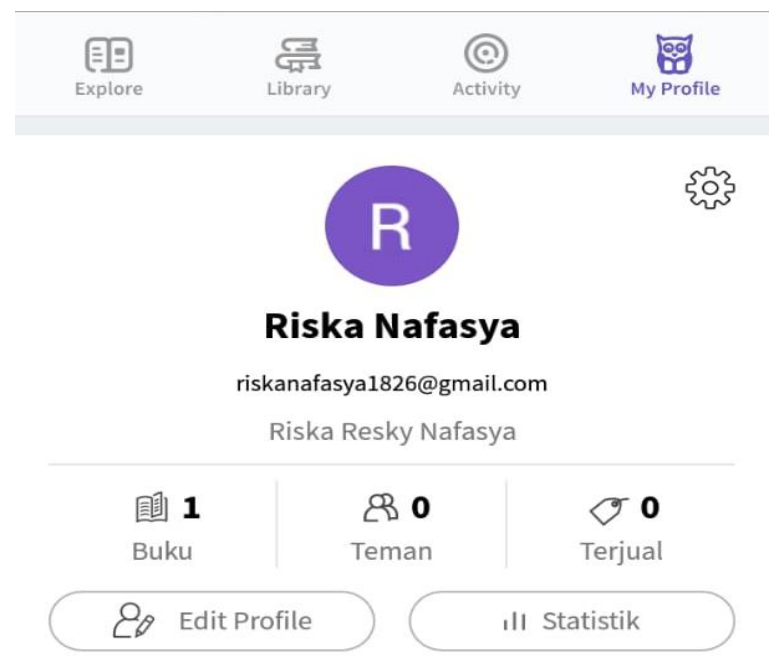

$\square$ Penjualan

Aktifkan Sekarang > Powered by Midtrans

Draft Tulisan 
Oktober 2019 Jurnal Pendidikan Bahasa dan Sastra Indonesia

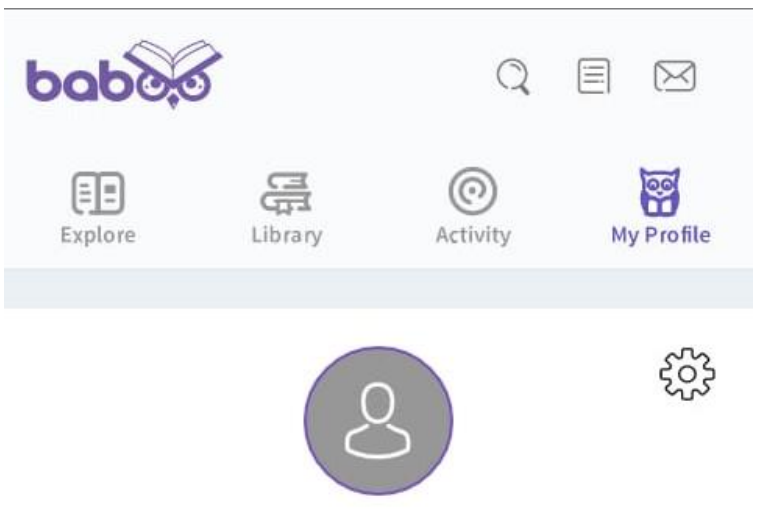

Ririn Andriani

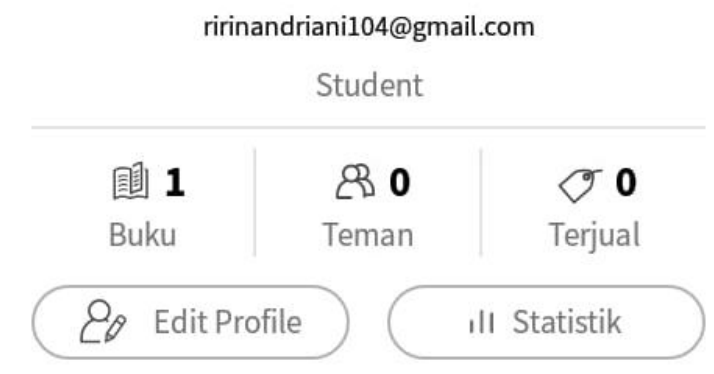

Penjualan

\section{Aktifkan Sekarang Power}

\section{Draft Tulisan}

Gambar 1 Penggunaan Aplikasi Baboo

\section{Uji Buku Ajar oleh Ahli}

Uji buku ajar oleh ahli di dalam penelitian ini dilakukan oleh ahli yang berkompeten dalam bidang buku ajar. Tujuan dari uji buku ajar yang dilakukan oleh ahli yaitu guna mengetahui kelayakan buku ajar untuk digunakan dalam pembelajaran. Ahli dalam uji buku ajar ini adalah Dwi Putri Fatmawati, M. Pd. Uji model oleh ahli dilakukan pada bulan Juli 2019. Data yang diperoleh dalam uji buku ajar ini yaitu data kuantitatif yang diperoleh dari angket tertutup dan data kualitatif yang diperoleh dari masukan dan saran untuk program yang dikembangkan.

Tabel 1 Hasil Penilaian Kelayakan Kumpulan Cerita Rakyat Antiradikalisme

\begin{tabular}{|c|c|c|c|c|}
\hline \multirow{2}{*}{ NO } & \multirow{2}{*}{ Penilai } & \multicolumn{3}{|c|}{ Hasil Penilaian Komponen } \\
\cline { 3 - 5 } & Kelayakan & Persen & Kategori \\
\hline 1 & Validator Media & $115 / 120$ & $95,8 \%$ & $\begin{array}{c}\text { Sangat } \\
\text { Baik }\end{array}$ \\
\hline 2 & Validator Materi & $58 / 60$ & $96,7 \%$ & $\begin{array}{c}\text { Sangat } \\
\text { Baik }\end{array}$ \\
\hline 3 & Respon Pengguna & $12 / 12$ & $100 \%$ & $\begin{array}{c}\text { Sangat } \\
\text { Baik }\end{array}$ \\
\hline
\end{tabular}

\section{Pre-Test dan Post-Test}

Pre-test dilakukan sebelum siswa diberikan bahan ajar berupa buku kumpulan cerita rakyat yang disertai dengan teori tentang cerita rakyat dan radikalisme. Hasil dari pre-test yang dilakukan pada 10 (sepuluh) orang siswa menunjukkan hasil sebagai berikut.

Tabel 2 Hasil Pre-test tentang Antiradikalisme

\begin{tabular}{|c|l|c|}
\hline No & \multicolumn{1}{|c|}{ Nama } & Nilai \\
\hline 1 & Muhammad Zafran Ramadhan & 40 \\
\hline 2 & Arsita Fitrianisa Putri & 50 \\
\hline 3 & Desianti Eka Hassanah & 65 \\
\hline 4 & Dinda Alfianita & 60 \\
\hline 5 & Gilang Hidayat & 50 \\
\hline 6 & Nastiti Kenanga Indah & 55 \\
\hline 7 & Ida Hidayati Shafaat & 60 \\
\hline 8 & Diva Mega Arianti & 65 \\
\hline 9 & Lili Bening Gumawang & 50 \\
\hline 10 & Fawaz Abimanyu Huraq & 55 \\
\hline & \multicolumn{2}{|c|}{ Rata-rata } \\
\hline
\end{tabular}

Berdasar hasil pre-test tersebut dapat dilihat bahwa pemahaman siswa tentang radikalisme mendapat nilai 55 atau berada pada taraf cukup. Hal ini tentu dapat ditingkatkan dengan pemberian materi tentang radikalisme pada siswa melalui pemahaman nilai-nilai pendidikan dalam cerita rakyat yang dibawa oleh siswa. Pemberian penekanan pada bab yang dibahas dapat meningkatkan pemahaman siswa pada suatu materi. (Utomo, 2017). Setelah itu, diberikan pemahaman tentang antiradikalisme pada siswa melalui bahan ajar berupa buku kumpulan cerita rakyat yang juga berisi materi tentang antiradikalisme. Selanjutnya, dilakukan post-test setelah pemberian materi antiradikalisme dan menunjukkan hasil sebagai berikut.

Tabel 2 Hasil Pre-test tentang Antiradikalisme

\begin{tabular}{|c|l|c|}
\hline No & \multicolumn{1}{|c|}{ Nama } & Nilai \\
\hline 1 & Muhammad Zafran Ramadhan & 90 \\
\hline 2 & Arsita Fitrianisa Putri & 90 \\
\hline 3 & Desianti Eka Hassanah & 100 \\
\hline 4 & Dinda Alfianita & 85 \\
\hline 5 & Gilang Hidayat & 85 \\
\hline 6 & Nastiti Kenanga Indah & 90 \\
\hline 7 & Ida Hidayati Shafaat & 85 \\
\hline 8 & Diva Mega Arianti & 90 \\
\hline 9 & Lili Bening Gumawang & 95 \\
\hline 10 & Fawaz Abimanyu Huraq & 90 \\
\hline & \multicolumn{2}{|c|}{ Rata-rata } \\
\hline
\end{tabular}

Berdasar hasil post-test tersebut dapat dilihat bahwa pemahaman siswa tentang radikalisme mendapat nilai 55 atau berada pada 
taraf cukup. Dapat disimpulkan bahwa penggunaan bahan ajar berupa buku kumpulan cerita rakyat dapat meningkatkan kompetensi literasi antiradikalisme pada siswa sekolah dasar.

Uji Praktisi Melalui Focus Group Discussion (FGD)

Uji praktisi dilakukan melalui FGD dengan menghadirkan ahli buku ajar, kepala sekolah, dan guru SD Negeri Tinom, Godean, Sleman. Uji praktisi dilakukan setelah dilakukan uji ahli dan mendapat nilai bahwa buku kumpulan cerita rakyat dan pembelajaran menulis melalui aplikasi Baboo layak untuk diimplementasikan. Dalam uji praktisi ini, data yang dihasilkan adalah data kualitatif. Data kualitatif ini diperoleh dari hasil masukan dan saran dari ahli buku ajar, kepala sekolah, dan guru SD Negeri Tinom, Godean, Sleman.

Pelaksanaan FGD ini terdapat beberapa rangkaian kegiatan di antaranya: (a) persiapan FGD yaitu menyiapkan buku ajar dan aplikasi Baboo yang sudah diujian oleh ahli; (b) buku kumpulan cerita rakyat dianalisis oleh praktisi yaitu ahli buku, kepala sekolah, dan guru SD Negeri Tinom, Godean, Sleman; (c) menelaah umpan balik yang sudah dilakukan. Adapun hasil dari FGD adalah sebagai berikut: (a) penyempurnaan tampilan dan tata letak ilustrasi; (b) memperbaiki penggunaan font pada buku kumpulan cerita rakyat.

\section{Penyempurnaan Produk}

Setelah melalui tahapan uji praktisi (FGD) yang dilakukan bersama kepala sekolah, guru, dan ahli dalam bidang buku ajar, maka produk disempurnakan sesuai dengan saran dari praktisi. Adapun revisi yang dilakukan yaitu 1) penyempurnaan tampilan dan tata letak ilustrasi, dan 2) memperbaiki penggunaan font pada buku kumpulan cerita rakyat.

\section{SIMPULAN}

Berdasar pada hasil di atas dapat disimpulkan bahwa penulisan cerita rakyat dengan aplikasi Baboo dapat digunakan untuk meningkatkan kompetensi antiradikalisme pada siswa. Hal tersebut dibuktikan dengan peningkatan nilai hasil dari pre-test dan post-test tentang antiradikalisme, yang mana nilai rata-rata pre-test yaitu 55 (lima puluh lima) dan nilai ratarata post-test siswa 90 (sembilan puluh). Selain itu, kumpulan cerita rakyat antiradikalisme yang disusun juga dinyatakan layak untuk digunakan sebagai bahan ajar melalui penilaian ahli media dan materi yang mana dari kelayakan penggunaan media diberi nilai 92 (sembian puluh dua), tentang kelayakan materi cerita rakyat diberi nilai 90 (sembilan puluh), serta diperkuat dengan hasil dari Focus Group Discussion (FGD) bersama ahli dan calon pengguna.

\section{DAFTAR PUSTAKA}

Hutapea, E. 2019. Literasi Baca Indonesia Rendah, Akses Baca Diduga Jadi Penyebab ed. Yohanes Enggar Harususilo dalam https://edukasi.kompas. com/read/2019/06/23/07015701/literasibaca-indonesia-rendah-akses-bacadiduga-jadi-penyebab diakses pada 12 Oktober 2019.

Kayati, A. N. 2019. Literasi dalam Teks Rekaman Percobaan Siswa Kelas IX SMP. Jurnal Metalingua. Universitas Trunojoyo, Vol. 4, No. 1, hlm. 31-38.

Yunus, A. F. 2017. Radikalisme, Liberalisme dan Terorisme:Pengaruhnya terhadap Agama Islam. Jurnal Studi Al-Qur'an. Vol. 3, No. 1, hlm. 76-94.

Mubarok, I. W. \& Pheni C. K. 2019. Efektifitas Penggunaan Bahan Ajar Berbasis Android Nemo Bahasa Indonesia untuk Mahasiswa BIPA Tingkat Pemula Program Darmasiswa Universitas Muhammadiyah Surabaya. Jurnal Metalingua. Universitas Trunojoyo, Vol. 4, No. 1, hlm. 19-24.

Utomo, A. A. 2017. Pengaruh Pemberian Penjelasan Guru terhadap Pemahaman Siswa pada Pelajaran Sejarah Siswa Kelas X IPS di SMA Negeri 1 Kalirejo Lampung Tengah Tahun Ajaran 2015/2016. Skripsi. Universitas Lampung. Skripsi tidak diterbitkan. 
Volume 4 No. 2 METALINGUA

Oktober 2019 Jurnal Pendidikan Bahasa dan Sastra Indonesia 